\title{
HISTORISITAS POLITIK PEREMPUAN INDONESIA
}

\author{
Wasisto Raharjo Jati \\ Pusat Penelitian Politik, Lembaga Ilmu Pengetahuan Indonesia \\ wasisto.raharjo.jati@lipi.go.id
}

\begin{abstract}
This article aims to analyze historicity of political participation and representation of women in the political landscape in Indonesia. This paper used the perspective of feminism theory as core analysis in reviewing its issue. Periodicity of Indonesian women's political participation is very volatile and depends on the political situation contemporary. Indonesian women's political participation in the era of colonialism experienced domestication, revivalism in the Sukarno era, stigmatization in the New Order era, and is now experiencing ambiguity in the Reformation era. Indonesian women's political participation need to find a strong platform to promote the aspirations of his people
\end{abstract}

Keywords: partisipation, representation, domestification, stigmatization, and women politic.
ABSTRAK

Artikel ini bertujuan untuk menganalisis historisitas partisipasi politik dan keterwakilan perempuan dalam lanskap politik di Indonesia. Tulisan ini menggunakan perspektif teori feminisme sebagai analisis inti dalam meninjau isu nya. Periodisitas partisipasi politik perempuan Indonesia sangat fluktuatif dan tergantung pada situasi politik kontemporer. Partisipasi politik perempuan Indonesia di era kolonialisme mengalami domestikasi, revivalisme di era Soekarno, stigmatisasi di era Orde Baru, dan sekarang mengalami ambiguitas dalam era Reformasi. Partisipasi politik perempuan Indonesia perlu menemukan platform yang kuat untuk memperjuangkan aspirasi rakyatnya

Kata kunci: partisipasi, representasi, domestifikasi, stigmasi, politik perempuan

\section{PENDAHULUAN}

Membincangkan relasi politik dengan politik formal adalah merupakan kepanjangan dari dominasi politik maskulin terhadap politik feminisme. Hal tersebut menguatkan argumentasi bahwa perjuangan politik perempuan untuk mendapatkan representasi politik formal adalah sesuatu yang tabu. Partisipasi politik perempuan pada akhirnya dimaknai sebagai subjek pasif dalam event pemilu maupun ajang politik lainnya. Secara garis besarnya, terdapat tiga poin penting alasan ketebatasan politik perempuan Indonesia dalam ranah politik formal (Nurland, 2005:236). Pertama, perempuan Indone- sia terjerat dalam kultur patriarki yang begitu kuat dalam kehidupan seharihari. Perempuan hanya menjadi objek subordinatif dari kaum lelaki yang menjadi pion utama dalam kemasyarakatan. Kultur patriarki sebenarnya dirancang untuk mendiferensiasikan dan mengultuskan ranah kehidupan baik pria dan wanita. Kaum pria menjadi entitas yang something sedangkan wanita menjadi entitas nothing sehingga timbullah pola domestifikasi wanita oleh pria. Konsep nothing tersebut mengindikasikan bahwa wanita "bukanlah apa-apa" tanpa adanya peran lelaki. Perspektif androposentrisme tersebut menegaskan bahwa pria lebih mandiri daripada wanita 
sehingga pria mempunyai fungsi autoritatif dan regulatif kepada wanita dalam wujud domestifikasi. Domestifikasi adalah upaya untuk menundukkan wanita melalui serangkaian norma, perilaku, maupun nilai maskulinitas. Domestifikasi paling nyata adalah wanita yang dipaksa bekerja dalam dua kaki antara pekerjaan rumah tangga dan berkarir yang keduanya menjadikan wanita tidak bisa bebas sesutuhnya menjadi entitas mandiri.

Kedua, doktrin agama yang masih konservatif dinilai terlalu mengekang kebebasan perempuan dalam ranah publik. Pemahaman ajaran agama Indonesia mempunyai kekuatan teologis untuk menundukkan posisi perempuan dalam kerangka inferioritas. Tanpa bermaksud berpretensi menjadikan lelaki menjadi imam bagi perempuan, pemahaman doktrin agama yang cenderung konservatif telah membatasi ruang gerak perempuan dalam berbagai hal yang kesemunya menempatkan lelaki menjadi pionirnya. Jika diperhatikan secara seksama, sebenarnya agama juga memberikan ruang-ruang bagi perempuan untuk berkreasi dan berekspresi. Namun demikian semua hal tersebut tertutupi dengan adanya kata "melindungi wanita" yang selalu dikutip dalam berbagai rujukan sumber teologis yang pada intinya memberikan kaum pria bertindak lebih atas kaum perempuan demi perlindungan tersebut. Dalil tersebut sebenarnya ambigu untuk ditafsirkan karena pada dasarnya perempuan juga bisa mandiri untuk melindungi dirinya sendiri. Terkhusus bagi masalah politik (jinayah), perempuan hanya cukup mendengarkan dan patuh kepada setiap apa yang telah diusulkan oleh lelaki dalam ruang tersebut. Pada akhirnya, antara kultur patriarki dan teologis kemudian bersinergis dalam membentuk konstruksi bahwa perempuan harus sepenuhnya berada dalam kekuasaan lelaki. Maka yang terjadi kemudian justru adalah menimbulkan perspektif bahwa lelaki adalah sumber dari segalanya (man is a measure of all things) sehingga menjadikan segala macam parameter maskulinitas menjadi sumber rujukan penting.

Ketiga adalah hegemoni negara yang hingga kini masih dipandang sebagai negara kaum laki-laki. Adanya pandangan tersebut sebenarnya ingin memberikan penegasan bahwa urusan negara sebagai urusan vital yang perlu diserahkan kepada kaum lelaki sebagai administrator dan eksaminator dan perempuan hanya menjadi asisten saja. Sebenarnya negara adalah ruang netral yang memberikan kesetaraan bagi siapa pun baik itu pria maupun wanita untuk bisa berkecimpung secara bersama dalam mengelola negara. Namun demikian, pemahaman negara justru terjebak pada masalah diferensiasi ruang yang sepenuhnya dibagi atas dikotomi maskulin dan feminin. Ruang publik mengindikasikan ruang tersebut merupakan bagian dari domain pria yang mencakup keseluruhan kehidupan maupun bermasyarakat sedangkan ruang privat sendiri mengindikasikan adanya ruang bagi perempuan yang utilitasnya sendiri hanya digunakan untuk memenuhi kebutuhan rumah tangga. Namun demikian, membincangkan hegemoni negara dalam upaya melakukan domestifikasi terhadap kaum perempuan rupanya lebih dari sebatas masalah ruang semata. Negara berupaya menetapkan berbagai macam produk-produk kultural yang berusaha untuk disematkan kepada kaum perempuan. Misalnya saja, fertilitas, reproduksi anak, gizi, maupun keluarga berencana yang kesemuanya dilakukan oleh berbagai saluran korporatisme negara seperti halnya Dasa Wisma, PKK, maupun Dharma Wanita yang sengaja dibentuk negara untuk 
mengklasifikan yang mana urusan lelaki serta yang mana urusan wanita. Adanya hegemoni negara tersebut memberikan pengaruh besar terhadap cara pola pikir bermasyarakat dalam melihat perempuan yang ingin berkiprah di dunia politik. Mayoritas pandangan tersebut akan tertuju pada perspektif bahwa dunia politik adalah hal yang tabu bagi perempuan dikarenakan dunia politik membutuhkan hard power, penuh dengan konspirasi, maupun penuh dengan segala intrik yang mengesankan bahwa dunia politik merupakan dunia yang kejam.

Adanya perspektif tersebut kemudian menimbulkan pemahaman biner baik kaum perempuan itu sendiri maupun bagi mereka yang sinis terhadap kiprah politik perempuan. Terkhususnya bagi perempuan sendiri yang menilai masuk arena politik formal adalah merupakan bagian dari upaya memperjuangkan aspirasi representasi mereka, tentu akan menilai sumir terhadap dunia politik. Adapun bagi mereka yang "sukses" menjadi politisi, keinginan untuk menjadi something dalam konstelasi politik parlementarian di Indonesia. para politisi perempuan hanya menjadi kontributor suara pasif dalam menyetujui RUU yang kesemuanya sudah dirancang oleh politisi pria. Ironisnya adalah ketika mereka ingin mendapatkan adanya rekognisi terhadap eksistensi mereka dalam politik parlemen. Para politisi perempuan ini harus mengikuti ramburambu politik maskulin sehingga secara tidak langsung mereka didorong untuk mengakui politisi pria sebagai pemimpin. Meskipun politisi perempuan sudah mampu mengeluarkan kebijakan yang pro gender seperti halnya UU Reproduksi, UU KDRT, UU Perlindungan Anak dan Ibu, UU Asisten Rumah Tangga, dan lain sebagainya. Substansi yang dikandung dalam UU tersebut ber- muatan upaya domestifikasi secara legal melalui pengedepanan isu-isu tersebut. Mereka akan terbebani dengan akan beban psikologis maupun beban kultural terhadap keinginan untuk berpolitik praktis dan akan lebih cenderung untuk mendelegeasikan aspirasi mereka terhadap politisi pria. Tentunya dengan melihat kenyataan tersebut sangatlah musykil untuk melihat kiprah perempuan lebih lanjut dalam memperjuangkan representasi politik maupun aspirasi kaumnya dalam ruang politik formal.

Tulisan ini akan mengurai secara lebih lanjut mengenai historiositas sepak terjang partisipasi politik perempuan hingga tahun 2013. Alasan dipilihnya historiositas sebenarnya adalah upaya untuk melacak kembali kembali perjuangan politik feminisme di Indonesia di tengah kepungan kultur patriarki maupun doktrin teologi yang konservatif. Adapun pelacakan terhadap akar politik feminisme dalam studi partisipasi politik Indonesia sebenarnya bermula pada konstruksi negara kolonial hingga masa pascakolonial yang menempatkan perempuan sendiri sebagai warga negara kelas dua. Namun demikian, partisipasi politik perempuan di Indonesia tentunya tidak bisa digeneralisasi sama rata. Dikarenakan kisah heorik terhadap perempuan juga muncul di berbagai daerah karena sistem matrilineal yang lebih diutamakan ketimbang patrilineal.

\section{FEMINISME DAN PROBLEMA REPRESENTASI POLITIK}

Feminisme sebagai sebuah alur metodologi keilmuan pada dasarnya bertitik lokus studi pada aspek ketertindasan perempuan oleh laki-laki yang kemudian berkembang menjadi sebuah gerakan pemikiran profetik dan empirik yang bersifat counter untuk melawan 
dominasi tersebut. Adapun counter ditujukan untuk melakukan dekonstruksi atas perspektif androposentrisme maupun maskulinisme yang menempatkan kaum pria sebagai entitas utama. Hal inilah yang kemudian mendasarkan kajian epistemologis feminisme dalam ruang politik sendiri meliputi tiga tugas utama yakni (1) mengetahui dimensi keterindasan tersebut, (2) mengetahui akar-akar dari ketertindasan tersebut, (3) memberikan solusi atas permasalahn tersebut. Hal inilah yang menjadikan penelitian feminisme sendiri bernuansa advokasi dan lebih mengutamakan subjektivitas peneliti dalam penelitian feminisme sehingga mampu merasakan dimensi ketertindasan tersebut (Hidayat,2006:32).

Oleh karena itu, tulisan ini menggunakan perspektif representasi sebagai bagian dari narasi besar "ketertindasan" tersebut. Representasi menjadi problem penting dalam situasi demokrasi kontemporer sehingga memunculkan sikap mosi tidak percaya dari publik kepada para pejabat pemerintah. Demokrasi yang diterapkan kini menyebabkan adanya pembajakan yang dilakukan oleh elite sehingga memunculkan adanya adanya representasi elite. Maka problema yang sebenarnya dalam iklim demokrasi sekarang ini adalah bagaimana mengembalikan kembali politik kepada sisi kebajikan dan sisi otentitasnya yakni formulasi penyaluran aspirasi dari publik kepada negara. Hal inilah mendorong adanya popular representation untuk menjamin semua elemen publik bisa tersalurkan aspirasinya kepada negara.

Adapun konsepsi popular representation tersebut pada dasarnya adalah model jembatan bagaimana representasi bisa memainkan fungsinya untuk menghubungkan antara demos dengan public affairs. Artinya dalam taraf ini terjadi alur representasi terjadi dalam dua ranah yakni formal dan informal di mana yang informal memiliki akses terhadap entitas formal. Hal inilah yang dimaksudkan dengan kanal rantai daulat populis (chain of popular sovereignty) yakni berintegrasinya kanal kekuatan politik ekstra-parlementarian dengan kekuatan politik intra parlementerian sehingga redistribusi representasi sendiri berjalan seimbang baik di tingkatan elite maupun publik (Tornquist, 2006:9).Adapun pola representasi politik sendiri yang dilakukan dapat berwujud tiga macam yakni representasi subtantif yakni pola representasi yang dilakukan atas bertindak untuk (acts for) terhadap objek maupun subjek yang diwakilkan. Representasi deskriptif berupa representasi yang dilakukan terhadap objek yang memiliki kepentingan atas kaumnya. Representasi simbolik adalah representasi sebagai bagian dari pengidentifikasikan diri untuk mewakili kepentingan kelompok yang lebih besar.

Terkait dengan relasi antara feminisme politik, representasi politik perempuan, maupun historiositas partisipasi politik perempuan Indonesia 2013 sebenarnya dapat diatrik suatu premis bahwa perjuangan politik perempuan Indonesia untuk mendapatkan kesetaraan yang sama dengan laki-laki sebagaimana yang diamanatkan dalam agenda feminisme belumlah memiliki basis kuat baik dalam perjuangan formal maupun informal. Artinya belum ada sinkronisasi antara gerakan politik perempuan ekstra-parlementarian dengan politik perempuan parlementarian. Hal ini dikarenakan adanya persoalan kultur representasi yang berbeda antara gerakan politik perempuan formal dengan informal. Adapun gerakan politik informal perempuan lebih mengarah pada pola representasi subtantif karena mereka secara nyata bertindak atas (acts for) atas isu perempuan yang diwakilinya. Sedangkan politisi 
perempuan yang duduk di parlementarian atau lembaga eksekutif lainnya lebih mengarah pada representasi simbolik yang hanya menjadi simbol penanda adanya perempuan memiliki wakil di arena politik formal. Sebenarnya dalam arena politik formal sendiri, politisi perempuan memiliki organ bernama Kaukus Perempuan Politik Indonesia (KPPI). Namun demikian keberadaan organ ini sifatnya hanya konsultatif saja dan lebih mengarah kepada perjuangan eksistensi dan kesetaraan suara politisi perempuan dalam memberikan suara dalam pembuatan maupun pengesahan undang-undang. Artinya dalam perjuangan politik perempuan lebih bercorak pada negosiasi ketimbang advokasi yang dianut gerakan politik informal. Hal itulah yang menjadikan gerakan politisi perempuan untuk memperjuangkan representasi perempuan tidak maksimal karena terbentur ramburambu maskulinisme dalam politik formal.

\section{DARI FEODALISME, REVIVALISME, D O M E S T I F I K A S I P O L I T IK PEREMPUAN}

Mendiskusikan sejarah partisipasi politik perempuan di Indonesia sebenarnya merupakan realitas unik. Jauh sebelum hadirnya tiga rambu maskulinisme hadir di Indonesia yakni patriarki, teologis, maupun hegemoni hadir pada abad 15, partisipasi politik perempuan sebenarnya banyak mewarnai narasi penting dalam kepemimpinan politik di Indonesia. Sebut saja, Ratu Shima, Tribhuana Tungga Dewi, dan Suhita di masa HinduBuddha. Ratu Kalinyamat di masa Islam, Cut Nya Dien, Christana Martha Tiahahu, maupun Nyi Ageng Serang di masa pergolakan kolonialisme. Dewi Sartika dan Kartini di masa akhir ko- lonialisme, hingga Megawati Soekarno Putri di masa kemerdekaaan. Rentetan panjang kepemimpinan politik perempuan baik ranah formal maupun informal sebenarnya menandakan bahwa perempuan Indonesia pada dasarnya memiliki kesadaran maupun partisipasi politik tinggi dalam memperjuangkan aspirasi kaumnya. Artinya ketiga rambu penghambat partisipasi politik perempuan yakni teologi, hegemoni, maupun patriarki tidak bisa dipukul rata dalam membaca keterbatasan emansipasi maupun representasi perempuan Indonesia. Adapun narasi penting partisipasi politik perempuan Indonesia adalah cerita yang pluralistik yang tergantung kepada kultur lokal yang berkembang yakni bilateral, matrilineal, maupun patrilineal yang kesemunya memiliki corak pandang khas terhadap perempuan Indonesia (Poerwandari, 2005:33). Doktrin teologis seperti islam dan Hindu-Buddha sebenarnya sudah memberikan tatanan penting dalam memberikan pengaruh gender dalam mendiferensiasikan perempuan dan pria sehingga kedua aktor tersebut bisa menghargai satu sama lain.

Penghancuran sistematis terhadap partisipasi maupun representasi politik perempuan di Indonesia bisa dilacak sejak munculnya negara kolonial Hindia Belanda pada akhir abad 17. Terdapat dua mekanisme politis yang digunakan untuk mendegradasikan posisi perempuan yakni dengan cara pergundikan dan feodalisme. Kebijakan pergundikan sendiri dilakukan untuk memenuhi rasa "kesepian" bagi para lelaki Eropa yang bermigrasi ke Hindia dalam rentang tahun 1890 dan 1920 mengalami peningkatan sejumlah 200 persen untuk bekerja baik di perkebunan, pemerintahan, maupun sektor lainnya. Hal itulah yang kemudian mendorong adanya praktik prostitusi legal yang mendorong banyak wanita Indonesia untuk menjadi 
"nyai" atau gundik bagi para orang kulit putih tersebut. Konsepsi "nyai" adalah upaya penghilangan sekaligus pelecehan martabat wanita Indonesia yang dilakukan secara psikis, bertujuan untuk membuat wanita Indonesia merasa inferior. Nyai sebagai bentuk kolonialisasi terhadap wanita Jawa dimanifestasikan dalam Berbagai panggilan merendahkan diberikan masyarakat Eropa kepada para nyai, mulai inlandse huishoudster (pembantu rumah tangga), meubel (perabot), inventarrisstuk (barang inventaris), boek (buku), hingga woordenboek (kamus) karena nyai berfungsi sebagai penerjemah suami dan/atau tuan mereka (Fitria, 2010). Nyai sendiri tidak memiliki ikatan hukum mengikat dengan majikannya meskipun terikat secara domestik. Semuanya tergantung pada keinginan majikan apakah akan memperpanjang masa kerja ataukah tidak.

Adapun dalam ranah pribumi, serangkaian norma dan nilai mulai dibentuk mengikuti perspektif seksisme yang dibangun oleh negara kolonial dalam mengatur kaum perempuan. Dalam konsep pribumi priyaya Jawa, mulai dikenalkan segala aturan domestifikasi terhadap perempuan yang pada intinya mengurangi kegiatan luar. Seperti halnya konsepsi kasur, pupur, dan sumur, pingitan, maupun selir yang kemudian berakhir pada pengukuhan kata wanita. Kata wanita pada mulanya adalah bentuk penghormatan terhadap perempuan seperti halnya lady dalam kosakata Inggris. Konsepsi wanita sebagai lady ditunjukkan dengan akronominya dari kalimat wani ing nata yang artinya perempuan mempunyai kemampuan dalam menata dan mengatur dalam berbagai permasalahan. Akronim tersebut kemudian diubah menjadi wani ditata yang kemudian memaknai hadirnya pria dalam mengatur perempuan. Konsep itulah yang kemudian melahirkan domestifikasi atas perempuan Indonesia secara meluas dan multidimensional. Patriarki kemudian dimunculkan bagian untuk mengukuhkan dominasi kelakian tersebut yang kemudian bersinergis dengan feodalisme.

Pengebirian representasi dan eksistensi perempuan dengan mengkaitkannya dengan fungsi seksualitas dan domestik juga didukung dengan adanya berbagai macam fatwa teologiskonservatif yang pada umumnya "membuat" perempuan menjadi makhluk patuh dan pasrah terhadap takdirnya sebagai perempuan makhluk lemah. Misalnya saja dilarang melawan suami, tidak boleh keluar rumah, wanita harus menurut pada pria sebenarnya mengindikasikan bahwa perempuan menjadi subordinasi bagi pria dalam berbagai aspek kehidupan. Patriaki sebagai sebuah sistem stratifikasi sosial dibakukan oleh negara kolonial dengan mengacu pada sistem sama di Eropa pada abad 14-15 dimana perempuan menjadi warga kelas dua. Patriaki sendiri diterapkan guna menjaga pengaruh politik politisi laki-laki agar tidak merasa tersaingi perempuan dengan mengkomodifikasi nilai kultur dan agama yang digunakan untuk mereduksi aktivisme perempuan.

Aturan tersebut muncul dengan seiring keluarnya peraturan negara kolonial untuk mendorong para bupati memiliki lebih istri lebih dari satu atau memelihara selir. Kebijakan tersebut ditempuh guna melindung kemurnian ras Eropa agar tidak tercampur dengan ras lain. Adapun kekuasaan bupati berbasis feodalisme yang diberlakukan oleh pemerintah negara kolonial rupanya memiliki muatan untuk mengukuhkan supremasi lelaki secara sistematis. Maka, kultur patriarki yang dibentuk selama feodalisme maupun kolonialisme sendiri kemudian memberikan pengaruh penting tentang na- 
sionalisme gerakan perempuan Indonesia pada akhir abad 19. Hadirnya Kartini maupun Dewi Sartika pada masa akhir tatanan kolonialisme negara kolonial dalam mengupayakan kesetaraan pendidikan bagi perempuan pada awal abad 20 sebenarnya memberika narasi penting dalam pembentukan gerakan politik ekstra parlementarian maupun revitalisasi eksistensi dan representasi politis bagi perempuaan Indonesia. Tulisan-tulisan Kartini yang dihimpun dalam buku Habis Gelap Terbitlah Terang mengritik patriaki, teologi, maupun hegemoni negara terhadap perempuan memberikan pengaruh besar terhadap timbulnya kesadaran kritisime perempuan dalam gerakan politik.

Tercatat bahwa revitalisasi representasi dan partisipasi politik perempuan Indonesia pada masa kebangkitan nasional maupun prakemerdekaan memberi andil besar dalam membentuk nalar berpolitik perempuan secara aktif maupun pasif (Sitasari,2010:24). Sebut saja, Puteri Mardika pada tahun 1920 yang memiliki afiliasi dengan Boedi Oetomo, Putri Indonesia, Wanito Tomo, Wanito Muljo, Wanita Katolik, Aisjiah, Ina Tuni dari Ambon, Jong Islamieten Bond bagian Wanita, Jong Java Meisjeskring, Poetri Boedi Sedjati, Poetri Mardika dan Wanita Taman Siswa. Adapun Kongres 22 Desember 2918 disebut sebagai tonggak penting dalam revitalisasi partisipasi dan representasi politik perempuan di Indonesia setelah sekian lama terpenjara oleh maskulinisme politik. Kongres tersebut melahirkan berbagai macam visi-misi gerakan politik perempuan Indonesia yang terhimpun dealam berbagai kongres lainnya seperti Kongres Perkumpulan Istri Indonesia, Kongres Perempuan Indonesia, maupun Kongres Perkumpulan Perempuan Indonesia. Kesemua substansi kongres tersebut pada dasarnya sama memperjuangkan ek- sistensi perempuan dalam segala bidang hingga menuju kemerdekaan Indonesia.

Era Presiden Soekarno memiliki atensi besar terhadap berkembangnya partisipasi dan representasi politik perempuan Indonesia melalui payung besar sosialisme maupun nasionalisme. Soekarno secara khusus menyebut perempuan Indonesia yang berjuang dalam ranah politik sebagai Sarinah yang peduli terhadap kepedulian kaumnya. Kedudukan Sarinah sama seperti halnya Bung sebagai pejuang politik laki-laki yang berjuang demi kemaslahatan bersama yang artinya tidak ada perbedaan satu sama lainnya (Soekarno,2001). Puncak dari segala aktivisme politik perempuan yang berkembang selama era Soekarno berkulminasi pada Gerwani (Gerakan Wanita Indonesia) yang memiliki afiliasi kuat dengan PKI. Gerwani disebut sebagai pelopor gerakan emansipasi politik perempuan terbesar di Indonesia dan juga di Asia. Militansi politik yang ditunjukkan Gerwani dalam mengangkat isu politik perempuan sangat tinggi termasuk menentang praktik poligami Presiden Soekarno yang dituding telah melecehkan harkat perempuan Indonesia.

Adanya insiden 1965 menjadi titik balik dalam perjuangan representasi dan eksistensi politik perempuan Indonesia. Adanya pemberangusan Gerwani dan segala macam bentuk gerakan perempuan Indonesia menjadikan perempuan Indonesia kembali lagi menjadi makhluk inferior. Hadirnya rezim Orde Baru hasil coup militer tersebut tidak menyukai aktivisme politik perempuan Indonesia terlebih lagi Gerwani yang cukup membuat pemerintah Order Baru untuk melakukan stigmatisasi terhadap aktivisme politik perempuan. Rezim mulai memberlakukan adanya politik seksual terhadap perempuan berbasis vagina detanta bahwa segala aktivisme gerakan politik formal dan informal 
yang dilakukan oleh perempuan berpotensi merusak bagi kehidupan berbangsa. Rezim berusaha mengkonstruksi dan mengkreasi politik perempuan sebagai entitas yang kotor seperti layaknya Gerwani ketika melakukan tarian Harum Bunga yang berbau erotis. Hal inilah yang kemudian memicu adanya label "Gerwanisasi" bagi setiap perempuan yang ingin memperjuangkan hak politik, yang seketika itu juga akan dicap pula sebagai wanita komunis oleh negara dan masyarakat (Wieringa, 2010). Rezim Orde Baru tetap mengakui adanya representasi dan partisipasi politik perempuan dengan mengubah gaya politik dari semula militansi menjadi partisipatoris-pasif. Aktivisme politik perempuan pada akhirnya mengalami enklavisasi sebagai bagian dari utusan golongan yang disamaratakan dengan kelompok minoritas. Maka pada akhirnya, representasi dan partisipasi politik perempuan hanya menjadi pencitraan simbolik selama Orde Baru berkuasa dimana keberadaan politisi perempuan hanya menjadi penggenap suara maupun tukang stempel kebijakan (political marker). Selama Orde Baru berkuasa, representasi dan partisipasi politik perempuan dalam panggung arena politik formal sangatlah fluktuatif. Indikasinya bisa kita simak dari pemilu 1971-1977, jumlah politisi perempuan hanya 7,8 persen, 1977-1982 hanya 6,3 persen, 1982 -1987 sebesar 8,5 persen, 1987-1992 sebesar 13 persen, dan 1992-1997 sendiri mencapai 12,5 persen (Ratnawati, 2004:298).

Rezim kemudian menerapkan adanya kebijakan "peran ganda" sebagai strategi subalternisasi partisipasi politik perempuan dimana perempuan memegang peranda ganda yakni sebagai warga negara, perempuan berhak untuk memperjuangkan hak politisnya dan sebagai ibu, perempuan haruslah mampu menjadi ibu rumah tangga yang baik dalam mengurus suami dan anaknya. Konsepsi tersebut kemudian dikenal sebagai "Ibuisme" yakni perempuan harus tampil sebagai sosok wanita yang bisa memainkan peran ganda tersebut (Suryakusuma,2011). Praktik subalternisasi politik perempuan Indonesia juga dilakukan melalui lembaga saluran korporatisme negara seperti Dharma Wanita, PKK, maupun Dasa Wisma yang lebih mendorong aktivisme politik perempuan berada di ranah rumah tangga. Hal itulah yang sebenarnya kemudian mengkonstruksi pemikiran publik bahwa sebaiknya perempuan lebih baik berkiprah dalam ruang privat saja ketimbang ruang politik saja. Konteks feminisme sendiri juga mengalami degradasi substansi menjadi feminim semasa Orde Baru untuk menampilkan perempuan Indonesia yang patuh dan taat kepada aturan dan setia kepada negara bangsa. Pendegradasian tersebut juga dimunculkan dengan diterapkannya kebaya sebagai bagian dari konstruksi wanita feminim tersebut untuk memberi penekanan atas tubuh politik perempuan sebagai sesuatu yang perlu dijaga oleh pria dalam kesehariannya.

\section{AMBIGUISME POLITIK PEREMPU- AN PASCA-ORDE BARU}

Tumbangnya Orde Baru pada tahun 1998 telah membuat banyak perubahan terhadap strategi dan aksi gerakan representasi maupun partisipasi politik perempuan di Indonesia. Hal tersebut ditandai dengan munculnya berbagai macam organisasi ekstra parlementarian perempuan di akar rumput seperti halnya Perempuan Mahardhika, Koalisi Perempuan Indonesia, Institut Perempuan, Gerakan Solidaritas Perempuan, dan lain sebagainya. Sementara itu, gerakan feminisme mulai 
mendapatkan tempatnya lagi dalam panggung politik formal dalam momentum liberalisasi politik dan demokrasi dengan diloloskannya angka $30 \%$ kuota politisi perempuan dalam UU No.12 Tahun 2003. Munculnya euphoria gerakan emansipasi politik perempuan dengan semakin meningkatnya kesadaran berpolitik di ranah informal maupun adanya affirmative action memang secara sekilas menjadi momen penting revivalisme gerakan feminism tersebut. Namun demikian, jika ditinjau lebih lanjut terdapat dimensi pascakolonialitas dalam membaca gerak politik perempuan Indonesia kontemporer. Pertama, adalah menguatnya tiga rambu politik maskulin yakni hegemoni, teologi, dan patriaki dalam ranah sosiopolitik maupun ruang sosio-kultural. Kedua, adalah ketidaksinkronan antara gerakan politik perempuan dalam ranah politik formal dan informal dalam memperjuangkan aspirasi politik perempuan sepenuhnya.

Pertama, dalam melihat kuota 30 persen tersebut. Pemberian kuota tersebut dapat dianalisa dalam dua hal yakni pengakuan negara terhadap kebebasan politik perempuan ataukah pembatasan terhadap representasi politik perempuan Indonesia. Dalam realitanya semenjak kuota 30 persen diterapkan. sembilan fraksi partai tidak satu pun yang menaati aturan $30 \%$ representasi politik perempuan tersebut. Perwakilan perempuan terendah di DPR RI adalah Partai Keadilan Sejahtera yang jumlahnya 5,3 persen, sementara Partai Demokrat memiliki keterwakilan tertinggi sebesar 24,3 persen. Adapun ketidak patuhan para partai politik atas aturan $30 \%$ menjadikan kuota itu tidak sungguhsungguh menciptakan ruang politik bagi perempuan di DPR, karena pada akhirnya kuota itu hanya dipakai untuk mentarget jumlah tertinggi. Kuota representasi 30 persen sendiri merupakan angka semu yang hanya digunakan untuk menggenapi jumlah kesetaraan gender anggota DPR, namun kuota 30 persen itu sendiri tidak menyentuh meningkatkan partisipasi politisi perempuan dalam pembuatan UU maupun kebijakan lainnya dan meningkatkan posisi tawar politik perempuan atas kebijakan publik tertentu yang sebenarnya itulah inti sebenarnya dari penerapaan kuota 30 persen representasi politik perempuan. Pada akhirnya kemudian kuota 30 persen adalah politik pencitraan yang menarasikan bahwa perempuan Indonesia diberi kebebasan berpolitik formal.

Selain itu pula dalam agenda elektoral di Indonesia, kuota 30 persen sebenarnya tidak dipatuhi secara nyata dan benar. Adapun sistem proporsional terbuka yang dianut di Indonesia yang mengedepankan sistem daftar terbuka cenderung diskriminatif terhadap perempuan. Dalam sistem urutan tersebut secara jelas bahwa urutan 1,2,dan 3 adalah angka psikologis yang cenderung menjadi pereferensi politik pemilih ketika mencoblos. Perempuan justru mendapati urutan bawah dalam sistem nomor urut tersebut karena dipandang tidak strategis untuk dipilih pemilih. Adanya diskriminasi tersebut sebenarnya menunjukkan bahwa kultur patriarki masih ada dalam penentuan kandidasi maupun konsensus kebijakan di ranah DPR. Hal tersebut belum ditambah Keengganan partai politik untuk memenuhi Peraturan KPU No 7 Tahun 2013 tersebut lantaran banyak didominasi paradigma domestifikasi perempuan yang selalu bekerja di rumah dan tingkat kepopuleran caleg perempuan yang dinilai masih kurang sehingga dikhawatirkan akan mengurangi angka elektabilitas partai tersebut atau berkurangnya proporsi bilangan pembagi pemilih (BPP). Penguatan doktrin teologi-konservatif juga muncul dalam 
status askriptif dengan achieved status yang merupakan akibat dari proses sosialisasi politik perempuan. Status askriptif sendiri dimaknai sebagai personifikasi politik perempuan sendiri yang masih minder dengan dunia politik yang identik dengan kekerasan karena sidang-sidang DPR maupun DPRD yang masih sarat konflik dan sesekali diwarnai kekerasan fisik, serta pergulatan tanpa henti untuk memperebutkan kedudukan dan kekuasaan merupakan beberapa hal yang menciutkan nyali perempuan untuk terjun dalam bidang politik. Mereka lebih suka menjauhkan diri dari politik kotor seperti yang dipertontonkan para politisi laki - laki tersebut. Adapun achieved status sendiri berkaitan dengan posisi ganda yang dialami perempuan untuk terjun sebagai wanita karir dalam bidang politik karena prestasinya mereka hanya bisa diakui kalau mereka sendiri mampu mengurusi urusan domestik rumah tangga terlebih dahulu, baru kemudian bicara representasi politik perempuan.

Kedua, menyoal ketidaksinergisan antara politisi perempuan di ranah formal dengan gerakan politik perempuan esktra parlementarian inilah yang menjadi masalah tersendiri dalam memperjuangkan feminism politik. Adapun dalam ranah politik formal sendiri, representasi dan partisipasi politik perempuan sendiri tidak berjalan secara maksimal dalam memperjuangkan aspirasi politik perempuan sesungguhnya. Perbandingan antara UU pro gender dengan UU non gender lebih banyak mengangkat yang non gender sehingga legalisasi agenda pro gender sangatlah minim. Yang terjadi justru dengan adanya kuota 30 persen, politisi perempuan lebih sibuk dalam agenda memperkuat eksistensi diri sebagai politisi perempuan yang ingin mendapatkan rekognisi politis dari sejawatnya politisi pria. Hal ini yang justru membuat representasi politik dalam kerangka feminisme hanya menjadi seremonial semata. Adapun gerakan politik informal yang selama ini militant dalam memperjuangkan aspirasi perempuan akar rumput justru tidak bisa menyalurkan aspirasi ke ranah politik formal. Selain halnya, representasi kuota 30 persen hanya seremonial belaka. Tentunya juga adalah stigmatisasi terhadap gerakan perempuan yang hingga kini masih mendapat diferensiasi politik, kultural, maupun teologis dari berbagai pihak. Oleh karena itulah, agenda politik perempuan Indonesia paska reformasi sendiri cenderung masih mencari platform yang tepat dalam merumuskan agenda politik feminisme di Indonesia.

\section{SIMPULAN}

Hal yang bisa disimpulkan dari tulisan ini adalah perjalanan panjang perempuan Indonesia dalam memperjuangkan representasi dan partisipasi politik feminisme belumlah sampai pada titik kesetaraan yang sama antara politik maskulin dan feminin. Adapun sejarah perempuan Indonesia sebenarnya adalah sejarah cerita mengenai kepemim-pinan perempuan tangguh. Namun kemudian hal tersebut mengalami perubahan seiring dengan berdirinya negara kolonial yang kemudian dengan latah melakukan pendisiplinan tubuh perempuan melalui patriarki, teologi, dan hegemoni. Revivalisme politik perempuan sempat hadir seiring dengan bekembangnya nasionalisme dan sosialisme. Namun kemudian, hal tersebut kemudian diberangus oleh rezim otoitarian yang menerapkan adanya domestifikasi terhadap perempuan secara ketat dan menyeluruh sehingga memicu adanya depolitisasi terhadap aspirasi perempuan. Adapun dalam masa demokrasi sekarang ini justru arah kejuangan 
representasi dan partisipasi politik perempuan menjadi ambigu. Hal ini dikarenakan ketidakseiringan agenda feminisme baik di ranah politik formal maupun politik informal. Kedepannya, semoga perempuan Indonesia mampu menempatkan dirinya secara sejajar dengan pria dalam berbagai bidang. Meskipun politik perempuan saat ini masih mengalami diskriminasi dan stigmatisasi, namun diskursus feminism akan selalu dinamis dan bergulir untuk menyadarkan publik akan pentingnya hak politik perempuan.

\section{DAFTAR PUSTAKA}

Hidayat, Rachmad.2006 "Kapan Ilmu akan Berubah ? Lebih Dekat dengan Metolodologi Feminisme". Jurnal Perempuan, 48(1): 27-37.

Nurland, Farida. 2005. "Strategies for Improving Women's Participation in Politics and Social Life", dalam A.W.
Soetjipto (ed). Politik Perempuan Bukan Gerhana. Jakarta: Kompas.

Poerwandari, Kristi. 2005. Indonesian Women in a Changing Society. Seoul: Ewha Women University Press.

Ratnawati. 2004. "Potret Kuota Perempuan di Parlemen".Jurnal Ilmu Sosial dan Ilmu Politik 7(3): 295-314.

Sitasari, Anita. 2010. The Future of Women in Indonesian Politics. New York: ProQuest.

Suryakusuma, Julia. 2011. State ibuism: The Social Construction of Womanhood in New Order Indonesia. Jakarta: Penerbit Komunitas Bambu.

Soekarno. 2001. Sarinah: Kewajiban Wanita dalam Perjuangan Republik Indonesia. Jakarta: Gunung Agung.

Tornquist, Olle. 2009. "Introduction: The Problem Is Representation! Towards an Analytical Framework". Dalam O. Tornquist (ed.). Popular Representation, Olle Tornquist (ed.). London: Palgrave Macmillan.

Wieringa, Saskia. 2010. Penghancuran Gerakan Perempuan: Politik Seksual di Indonesia Pasca Kejatuhan PKI. Yogyakarta: Galang Press. 